\title{
DOES THE PRESENCE OF INDEPENDENT DIRECTORS REDUCE THE PRACTICES OF EARNINGS MANAGEMENT? THE MODERATING ROLE OF FAMILY OWNERSHIP CONCENTRATION
}

While often criticized, the independence of directors remains a crucial criterion for evaluating the effectiveness of the monitoring role of boards. This study examines the relationship between board independence and earnings management, paying attention to moderation role of family ownership concentration on this relationship using a sample of services companies listed on Amman Stock Exchange ASE. This study documented a significant and negative association between board independence and earnings management. In addition, the moderating role of family ownership concentration on this relationship was also negative. Thus, the board's monitoring function was inefficient due to the concentration of ownership. These results were obtained through using multiple and sequential regression analysis for the research data from 2013 to 2016. This study provides new ideas for future research such as examining the impacts of the migration of capitals and investors from neighbouring countries such as Syria and Iraq.

Keywords: board independence, family ownership, earnings management, Amman Stock Exchange

* D. Al-Deen Al-Sraheen, Ph.D., Faculty of Business, Al-Zaytoonah University of Jordan, Jordan (E-mail: Deaa.Sraheen @zuj.edu.jo).

${ }^{* *}$ K. Ahmad Al Daoud, Ph.D., Faculty of Economics and Administrative Sciences, Yarmouk University, Jordan (E-mail: khaldoon.aldaoud@yu.edu.jo).

The paper was received on January 30th, 2018. It was accepted for publication on June 26th, 2018. 


\section{Introduction}

Various previous research has widely believed that flexibility in reporting may provide a channel for corporate managers through which they can opportunistically manipulate earnings, which, in turn, may negatively affect earnings quality and its use in the process of decision-making (Chang, Hwang, Li \& Jhou, 2018; Poretti, Schatt \& Bruynseels, 2018). The financial scandals surrounding several large firms in the last decade (e.g., Xerox, Enron, WorldCom, Tyco, HealthSouth, Waste Management, Sunbeam and Rite Aid) have raised dangerous concerns regarding the mechanisms of governance particularly the effectiveness of monitoring tools that used by companies to insure the interests of shareholders and investors (Shin \& Park, 2018). Board independence deemed as one of the corporate governance mechanisms that widely viewed as a tool to limit the costly managerial incentives. Therefore, previous research has been documented that the boards with majority directors who are independence have a much ability to perform controlling and monitoring of opportunistic behaviours (Fan, 2017; Chee, Phua, \& Yau, 2016).

The proportion of independent directors on the board improve earnings quality and the reliability of the financial statements through reducing earnings management. Davidson, Goodwin-Stewart \& Kent (2005). Found an empirical evidence for the effective function of directors' independent in limiting the practices of earnings management among Australian firms. Alves (2014) concluded that independent members of board enhance the quality of corporate earnings through controlling the behaviour of corporate managers to limit earnings management practices for a sample of Portuguese listed firms.

Leuz et al. (2003) pointed out that there is a higher level of earnings manipulation practices in countries with low protection of investor. In addition, assorted studies have documented that the concentration of family ownership influences earnings quality and corporate performance as well, where Ali, Chen and Radhakrishnan (2007) documented that reported earnings of family firms are of better quality and face less severe agency problems that arise from the separation of ownership and management. But they (Ali. et al., 20107) pointed out that family firms are less likely to make voluntary disclosures about their corporate governance practices. Labelle, Hafsi, Francoeur and Amar (2018) reported that family firms exhibit lower corporate social performance than non-family firms. They also found that family ownership concentration serving in stakeholder-oriented countries are more attentive to social concerns than those operating in more shareholder-oriented countries.

Liu, Wilson and $\mathrm{Wu}$ (2017) found that family firms also engage in less accrual-based earnings management, although they are indistinguishable from non- 
family firms in terms of real earnings management. A reason we study family ownership concentration (family firms) is that the significance and effect of the mechanisms of corporate governance to which they are subject vary in significant ways from those of non-family firms.

In prior studies such as Alzoubi (2016) documented that family firms are found to have less independent directors on the boards, suggesting that the controlling family prefers controllable board. In Jordan, over $45 \%$ of firms are controlled by family, and they are active in management aspects and engaging in various positions in management and tend to be passed on from one generation to another which means that they are seeking to retain control over the corporate management within family, and therefore suggest that the controlling family has motives to limit monitoring function of the board. In addition, an absence of market for firm control in Jordan can lead the family managers even more entrenched (Alzoubi, 2016, Sraheen, 2014). This study explores whether the domination of family members on corporate boards moderates the effectiveness of the monitoring function of independent boards. Such an issue considered one motivation in conducting the current research because two opposing views exist on the influence of family firms on independence boards and earnings management (Jiraporn, \& DaDalt, 2009). These viewpoints will be discussed in the coming sections.

This study may be conceivably beneficial as a supporting major for regulatory action, particularly those that influence the corporate ownership structure. The results have important implications for supervisors as well regulators, who will benefit by the understanding of how the structure of corporate ownership affects earnings management and enhance the level of financial reporting quality. This study also offers important contributions to both the literature and methodology. First, this study is one of the first few studies illustrating the moderated effect of family-controlled firms on the relationship between effectiveness of monitoring role of boards and earnings management. Second, this study also contributes to the understanding the importance of the role of independent boards of directors in Jordan, which is understudied in the previous literature such as Jaggi, Leung and Gul (2009) and Sraheen, Fadzil and Ismail (2014).

Since the 1990s, the reform of corporate governance has been a significant item in the Jordanian agenda to pursue sustainable and strengthened growth in various aspects of the Jordanian economy. The establishment of three new institutions, the Securities Depository Centre (SDC), the Amman Stock Exchange (ASE) and the Jordan Securities Commission (JSC), has contributed positively to an improvement in the Jordanian business environment (Jaafar \& El-Shawa, 2009). Despite such efforts directed at improving the regulatory environment and the practices of Jordanian corporate government, an evaluation made in 2004 by the World Bank and International Monetary Fund (IMF) pointed out that the situation 
of corporate governance in Jordan remains at a relatively underdeveloped stage (Berg \& Nenova, (2004). Such a statement is unsurprising, given that corporate governance is deemed a new concept in Arab countries. The report shows that the institutional framework suffers from a lack of enforcement capabilities and suffers from political interference.

In addition to the above, several studies conducted in the Jordanian environment have indicated that most Jordanian companies have practiced earnings management in their statements. The consequences of practices of earnings management are beyond doubt detrimental, decreasing the value of a company, its transactions, its image and its reputation, (Sraheen \& Saleh, 2017; Ajeleh \& Hamdan, 2009). These detrimental consequences are in addition to the fear of the collapse of large firms as has happened in developed countries, as mentioned previously (Rodriguez-Ariza, Rodriguez-Ariza, Martínez-Ferrero, Martínez-Ferrero, Bermejo-Sánchez \& Bermejo-Sánchez, 2016).

The current study produced its primary contribution through empirically showing that the structure of corporate ownership has various implications on earnings management. Moreover, the findings of the current study recommended that both researchers and policymakers would no longer consider corporate ownership structure as a whole, given that the structure of ownership has diverse implications on earnings management measured by the discretionary accruals.

The main motivation for the current study is to address a literature gap in the board monitoring efficiency and the institutional structure that affects the boards monitoring tasks by analysing data from an emerging market such as Jordan who's institutional and regulatory landscapes are markedly different from those of developed countries. The study seeks to provide new insights into the role of board independence on the reduction of earnings management practices and the moderating role of the concentration of family-ownership on this relationship, as well as highlight the need for further reform in the business and regulatory environment.

\section{Literature and hypothesis development}

\subsection{Board independence and earnings management}

Corporate boards are formed for purpose monitoring and controlling corporate managers on behalf of the corporate owners and shareholders. Agency theory stresses that the presence of independent directors has a positive influence on board effectiveness. In addition, the argument has been made that independent 
members who dominate boards are in a better position to control and monitor the behavior of corporate managers. Consequently, independent members serving on a board may play a vital role in monitoring the stages of preparing of financial statements by the corporate management (Frankel, McVay \& Soliman, 2011).

The influence of director independence on boards has been illustrated in many previous studies. The majority of this research has emphasized the role of independent directors in corporate boards in improving the monitoring function of the corporate board to monitor managerial activities and the behaviours of the managers as well. Davidson, Goodwin-Stewart, and Kent (2005) documented that corporate boards with majority of independent directors limits the practice of earnings management. Marra, Mazzola and Prencipe (2011) also pointed out that including non-executive directors on a corporate board plays a vital role in constraining the practices of earnings management. Chen, Knechel, Marisetty, Truong, and Veeraraghavan (2016) showed that the independence of board members was closely related with the timely addressing of the weaknesses of internal control.

To effectively perform their monitoring and advising tasks, the independent directors must have a substantial amount of detailed information regarding a firm's activities. In some scenarios, the environment of corporate information is opaque, and to acquire the necessary information regarding operating, investing and financing activities of firms is deemed costly; thus, independent directors in these corporate boards would be less effective (Armstrong, Core \& Guay, 2014). Therefore, to keep both independent directors and corporate owners informed about the various activities and the performance of management as well, the management has a fiduciary responsibility to offer detailed information to these parties. Such transparency may be impaired when insiders dominate the corporate boards (Chen, Cheng \& Wang, 2015; Daoud et al., 2015).

On the other hand, Daghsni, Zouhayer \& Mbarek (2016) have been documented in their study that there is no effect of the board independence on the earnings management among French companies. In addition to this point of view, the concept of independence in the current study refers to independence of mind rather than independence of appearance. The appointment of non-executive (independent) directors is subject to the discretion of corporate top managements, and thus it may not reflect the meaning of "truly independence". Therefore, based on such divergence of views on this relationship, the first hypothesis is set as follows:

H1: A high proportion of non-executive directors (independent directors) on the board reduces earnings management practices. 
D. A.-D. AL-SRAHEEN, K. A. AL DAOUD: Does the presence of independent directors reduce the practice of earnings... EKONOMSKI PREGLED, 69 (6) 638-654 (2018)

\subsection{Board independence and earnings management in family-controlled companies}

It has been argued previously (see, for example, Chen \& Jaggi, 2000) that because of the scattering of institutional capital, the powers of owners have conferred upon corporate managers. Corporate managers have less-specific targets than firms due to variety of ownership structures among shareholders in firms, so corporate managers can exert political influence to maintain their powers more systematically (Al-Sraheen \& Alkhatib, 2017). Thus, the argument suggests that activities of corporate managers must be properly tracked to avoid the abuse of power and opportunistic behavior, such as the maximization of their own wealth (Khalil \& Ozkan, 2016). It has been documented that a higher percentage of independent members on boards facilitates the monitoring task and limits managerial opportunism (Khalil \& Ozkan, 2016; Chen et al., 2015).

The key concerns in this research are centred around the independence of directors, which is more likely to be compromised when family controls a firm either through appointing family members to the board or ownership domination. That is because family members can control the appointment of independent directors appointment (independence in appearance) (Chen \& Jaggi, 2000). These so-called independent directors on such boards are less likely to go against the wishes and policies of controlling family members, particularly when they work as members of corporate boards.

Family-owned shareholdings account for a high proportion among Jordanian firms as Jaafar and El-Shawa (2009) document. They mentioned in their results that more than $51 \%$ of Jordanian listed firms are family-owned firms. Because of the concentration of family ownership, the mechanisms of market monitoring are poor in Jordan; mergers, acquisitions and hostile takeovers are almost non-existent in the Jordanian context. In addition, due to the concentration of family ownership, the shareholdings of institutional are not very common either (Jaafar \& El-Shawa, 2009). Jordanian firms also differ from other firms in nearby countries firms regarding generating funds; private borrowing through financial institutions such as banks is more common in Jordan rather than public debt (Alkhawaldeh, 2012).

The family ownership concentration as a phenomenon in Jordan and has led to divide the shareholders into two distinct categories, i.e., minority and majority shareholders. As a result of such categories of shareholders, family companies are likely to suffer from conflicts between minority and majority shareholders. Boards with a majority of family members will have an incentive to expropriate the interests of minority shareholders, therefore, they will have an opportunity to limit both controlling and monitoring function by the independent directors they appoint. In addition, their independence is possibly adversely affected and compromised 
because of their loyalty and closeness to the controlling family that has appointed or reappointed them to the boards. Thus, this study develops posits the following hypothesis to investigate this expectation:

$\mathrm{H} 2$ : The relationship between board independence and earnings management is moderated by family ownership concentration.

\section{Research methodology}

This section highlights the process of sample selection, sources of data collection and the description of the measurements of research variables.

\subsection{Sample data collection sources}

The impact of board independence on earning management in Jordan is investigated in this study. In addition, the moderating role of family ownership on the association between independence of board and earning management is explored in this study. The initial sample of this study includes all services companies whose stocks were listed in the Amman Stock Exchange over the period 2013 to 2016. There were 148 firms, and the final sample included 72 firms, which comprised $49 \%$ of the initial sample. All firms that did not have enough data were omitted. This led to 288 firm-year observations in total over four years, and the required research data were hand-collected from the annual financial reports of the companies that were annually submitted to the Amman Stock Exchange from 2013 to 2016.

\subsection{Models and measurements of the study}

This study proposes two models. The regression model is used in testing the impact of board independence on earnings management. Moreover, the current study considers the moderating effect of family ownership concentration on the relationship between independence of board and earnings management in the context of Jordan. For the purpose of reaching this objective, this study uses the sequential regression analysis (also called hierarchical regression) to test the moderation hypotheses and ascertain the effects of family ownership concentration 
as a moderating variable on the association between independence of board and earning management.

The following are the models of the study:

Model (1): examines the effect of board independence on earning management:

$$
E M_{i t}=\beta_{0}+\beta_{1} B I N D_{i t}+\varepsilon_{i t}
$$

Model (2): examines the moderating role of family ownership concentration on the association between independence of board and earning management.

$$
\mathrm{DAC}_{i t}=\beta_{0}+\beta_{1} B I N D_{i t}+\beta_{2} F A O W_{i t}+\beta_{3} B I N D * F A O W_{i t}+\varepsilon_{i t}
$$

Where:

DAC = Discretionary Accruals measured by the Modified Jones Model

BIND = Board Independence

FAOW = Family Ownership

BIND*FAOW = Interaction between board independence and family ownership

There is a long history of the research on earnings management, and Healy and Wahlen's (1999) definition is one of the most widely accepted definitions of earnings management. They defined earnings management as "Earnings management occurs when managers use judgement in financial reporting and in structuring transactions to alter financial reports to either mislead some stakeholders about the underlying economic performance of the company or to influence contractual outcomes that depend on reported accounting numbers" (p. 368). The accounting accruals approach is used in the current study as proxy of earnings management, this measurement called the Jones' (1991) model, which was revised later by Dechow and Sloan (1996). Some previous research such as Dechow, Sloan and Sweeney (1995) have analysed alternative measurements of accrual-based approaches for discovering earnings management and documented that the most powerful measurement is the modified Jones model developed in 1991 (Al-Sraheen \& Alkhatib, 2017). The non-discretionary accruals (ND) is calculated using equation (1)

$$
\frac{T A_{i t}}{L T A_{i, t-1}}=a_{1}\left[\frac{1}{L T A_{i, t-1}}\right]+a_{2}\left[\frac{\Delta R E V_{i t}-\Delta R E C_{i t}}{L T A_{i, t-1}}\right]+a_{3}\left[\frac{P P E_{i t}}{L T A_{i, t-1}}\right]+\varepsilon_{i}
$$

Here, TA refers to Total Accruals; LTA = Lagged Total Assets; $\triangle \mathrm{REV}=$ Change in Revenues from the preceding year; $\Delta \mathrm{AR}=$ Change in Accounts 
Receivable from the preceding year; PPE represents firm's gross property, plant and equipment. Meanwhile, $\alpha 1-\alpha 3$ entail the regression parameters and refers to equal error term.

Discretionary accruals (DA), equation (2) below, are calculated as the residual value after deducting non-discretionary accruals from the total accruals.

$D A=\frac{T A_{i t}}{L T A_{i, t-1}}-\left[a_{1}\left[\frac{1}{L T A_{i, t-1}}\right]+a_{2}\left[\frac{\Delta R E V_{i t}-\Delta R E C_{i t}}{L T A_{i, t-1}}\right]+a_{3}\left[\frac{P P E_{i t}}{L T A_{i, t-1}}\right]\right]$

As for family firms, this study adopts the $10 \%$ or more as threshold for classifying firms as family owned and controlled. Such a measurement was used by previous research such as Chen and Jaggi (2000).

The independent director is a dummy variable that takes a value of 1 if director is independent and 0 if otherwise (Cavaco, Challe, Crifo, Rebérioux, \& Roudaut, 2014).

\section{Results}

\subsection{Descriptive statistics}

Descriptive statistics have the primary objective of describing the elementary structures of the data. The statistics offer a simple summary about the study's variables. The descriptive statistics for the sample comprise 288 observations while the average of the sample over four years is for the 72 firms employed in the regression analysis for the period of 2013 to 2016. These are presented in Table 1. The mean of earnings management for the Jordanian firms is about $9.67 \% \%$, ranges between about $34.5 \%$ and $-31.0 \%$ on average, the research sample records positive discretionary accruals. This may indicate that Jordanian listed companies in this study are managing their earnings upwardly. This result is close to the finding of Al-Fayoumi, Abuzayed, and Alexander (2010) who reported the average of discretionary accruals was $12 \%$ in their study. 
Table 1.

\section{DESCRIPTIVE STATISTICS}

\begin{tabular}{|l|c|c|c|c|c|}
\hline Variable & $\mathrm{N}$ & Minimum & Maximum & Mean & Std. Deviation \\
\hline EM & 72 & -31.00 & 34.50 & .0967 & 21.78915 \\
\hline BIND & 72 & .00 & 1.00 & .3889 & .49092 \\
\hline FAMOW & 72 & .00 & .86 & .5816 & .20808 \\
\hline
\end{tabular}

The average board independence was $38.89 \%$, which shows that the Jordanian firms were committed to the recommendations of corporate governance code that at least one third of the members of the board director should be independent. Such a result is higher than the result of Marashdeh (2014) who reported an average was 24\%, which used the data from 2002-2010. Thus, this was deemed as indicator that Jordanian companies became highly committed to the rules of Jordanian corporate governance after the issuance of Jordanian Code of Corporate Governance in 2009. The statistics results show that the average value of family shares of the companies in the sample held by family members comprised $58.16 \%$ at the $10 \%$ ownership threshold. Family ownership represents $58.16 \%$ of the capital of Jordanian companies compared to 38\% for listed firms in Malaysia (Tam \& Tan, 2007). The result of this current study was higher than the result of Marashdeh (2014) who documented that the mean of family ownership of industrial and services Jordanian companies listed on the ASE was 45\%.

\subsection{Correlation analysis}

The Pearson Correlation is commonly used in the measurement for the presence of correlations among variables and in demonstrating if a statistically substantial linear association is present between variables and the direction and the strength and of a linear association. The Pearson Correlation coefficients among the variables are presented in Table 2. In this study, the correlation coefficients among the variables in the correlation matrix were all less than 0.90 showing that multicollinearity (one of regression assumptions) is not an issue within the regression models (Hair, Black, Babin, Anderson, \& Latham, 2010; Tabachnick \& Fidell, 2007). In this study, the Pearson Correlation matrix shows that the highest correlation was between independence of board (BIND) and earnings management (EM) and the value of correlation was (0.449). 


\section{Table 2.}

\section{CORRELATION MATRIX}

\begin{tabular}{|c|c|c|c|}
\hline & EM & BIND & FAOW \\
\hline EM & 1 & $-.449^{* *}$ & $.256^{*}$ \\
\hline BIND & & 1 & .036 \\
\hline FAOW & & & 1 \\
\hline
\end{tabular}

\subsection{Regression analysis}

This study used multiple regression analysis to compute the relationships between board independent and earning management. The results of regression analysis in Table 3 indicate that the adjusted $\mathrm{R}^{2}$ value for the Model was 19\%, which demonstrates that $19 \%$ of the variance of earnings management was explained by board independence. This study suggests adding new corporate governance variables such as CEO duality, audit committee and managerial ownership to the current research model in order to enhance the explanatory capacity $\left(\mathrm{R}^{2}\right)$ of the current model.

Results indicate a statistical significance association between board independence and earning management (F-statistic $=17.634, \mathrm{p}=0.000)$, which means that the model expressively elucidates the difference in earning management among the listed firms in Jordan. In addition, the direct relationship between board independence and earnings management was negative and significant $(t=-4.199 ; \mathrm{p}=$ .0.000). Such results indicate that a higher proportion of independence members on the board constrains the practices of earnings management among in Jordanian context. Boards with a higher number of independent directors have a higher ability to monitor the opportunistic behaviours of managers; this result is consistent with Fan, (2017) and Chee, Phua, and Yau (2016).

This study employed sequential regression analysis to determine whether family ownership does indeed moderate the association between independence of board and earnings management. As evidenced by the outcomes of the sequential regression analysis in Table 3, family ownership positively moderates the association between independence of board and earning management.

The following table is a summary of the sequential regression model. The table below describes the results of moderating role of family ownership concentration on the relationship between board independence and earnings management. 
D. A.-D. AL-SRAHEEN, K. A. AL DAOUD: Does the presence of independent directors reduce the practice of earnings... EKONOMSKI PREGLED, 69 (6) 638-654 (2018)

Table 3.

SEQUENTIAL MODERATED REGRESSION ANALYSIS RESULTS

\begin{tabular}{|l|c|c|c|c|c|c|}
\hline & \multicolumn{2}{|c|}{ Step 1 } & \multicolumn{2}{c|}{ Step 2 } & \multicolumn{2}{c|}{ Step 3 } \\
\hline Variables & \multicolumn{2}{|c|}{ I.V } & \multicolumn{2}{c|}{ Moderate } & \multicolumn{2}{c|}{ BIND*FAOW } \\
\hline Main Effect & $\mathrm{t}-$ value & $\mathrm{Sig}$ & $\mathrm{t}-$ value & $\mathrm{Sig}$ & $\mathrm{t}$ - value & $\mathrm{Sig}$ \\
\hline BIND & -4.199 & .000 & -4.468 & & 1.287 & \\
\hline Moderate Effect & & & & & & \\
\hline FAOW & - & - & 2.655 & .010 & 3.602 & .001 \\
\hline Interaction Effect & & & & & & \\
\hline BIND*FAOW & - & - & - & - & -2.505 & .015 \\
\hline $\mathrm{R}^{2}$ & 0.449 & & .525 & & .580 & \\
\hline Adjusted R ${ }^{2}$ & .190 & & .254 & & .307 & \\
\hline $\mathrm{R}^{2}$ Change & .201 & & .074 & & .061 & \\
\hline F sig. Change & .000 & & .010 & & .015 & \\
\hline
\end{tabular}

The results show that the research model was significant at the 0.05 level of significance $(t=-2.505 ; \mathrm{p}=.015)$. The findings of the moderating regression indicate also that the family ownership concentration affected adversely the relationships between board independence and earnings management. This means that the presence of family members on the corporate boards mitigates against the effectiveness of the boards and their monitoring function. Therefore, boards with independent directors and family concentration should be considered independent in appearance only. This practice harms the efficiency of the boards and gives space to the corporate managers to practice their opportunistic behaviours. Such finding is also supported by the prior studies such as Mengoli, Pazzaglia \& Sandri (2017) and Kazemian and Sanusi (2015) who have been documented in their study that ownership concentration is negatively to earnings management.

The findings of the current study are consistent also with the survey findings on Hong Kong companies, which pointed out that most companies with a concentration of family ownership appoint family members on corporate boards to take care of their own interests (Ho \& Wong, 2001). It has also been noted in other research that boards with a majority of family members also hold executive positions in the company. Such a case creates a unique situation with respect to the domination of family ownership with the control of the firm. Because of the domination of family, the agency conflict shifts from a shareholder-manager conflict to a minority-majority shareholder conflict (Claessens \& Fan, 2002). 


\section{Conclusion}

The aim of current study was to investigate the effect of board independence on earnings management. In addition, this study sought to identify the role of family ownership concentration on the relationship between board independence and earnings management. The study found that a negative and significant association existed between board independence and earnings management. This means that the existence of independent directors on the board will restrict the opportunistic behavior of corporate managers. On the other hand, the study concluded that family ownership concentration on the corporate board will harm the independence of board members, and will provide managers with more opportunity to manipulate the earnings.

This study makes several new contributions. First, the results of this study may contribute by limiting the agency conflict, where the independent board members may have an important monitoring function of the financial reporting process and are therefore expected to insist on better earnings quality by reducing earnings management practices. Second, a focus on Jordan is important because family ownership concentration is high, which impedes all the monitoring tools proposed by corporate governance such as the independence of board members as stated in the results of this study. Such concentration of ownership is exist in various countries, and therefore, the results of the current study are generalizable. Such results may assist decision makers in providing a set of instructions to ensure the quality of the financial information reported in the financial statements by limiting the negative effect of ownership concentration on that information.

There are various potential opportunities to be considered in the future for more research and improvements. For example, foreign ownership and its impact on the earnings management and the quality of financial statements. Especially after the migration of Syrian and Iraqi capitals and investors to Jordan due to the political and security situation in that countries.

Acknowledgment: Thanks to Tim Walters,waltim5@gmail.com, for his editorial services.

\section{References:}

Ajeleh, I., \& Hamdan, A. (2009). The impact of corporate governance on earnings management: Evidence from Jordan. The international financial and economic crisis and global governance. Oct. 2009 
D. A.-D. AL-SRAHEEN, K. A. AL DAOUD: Does the presence of independent directors reduce the practice of earnings.. EKONOMSKI PREGLED, 69 (6) 638-654 (2018)

Al-Fayoumi, N., Abuzayed, B., \& Alexander, D. (2010). Ownership structure and earnings management in emerging markets: The case of Jordan. International Research Journal of Finance and Economics, 38(1), 28-47.

Ali, A., Chen, T., \& Radhakrishnan, S., (2007). Corporate disclosures by family firms. Journal of Accounting and Economics, 44(1-2), 238- 286.

Alkhawaldeh, A. A. (2012). Effects of family and foreign ownership structure on Jordanian credit risk assessments. International Research Journal of Finance and Economics, 90, 92-113.

Al-Sraheen, D., O., \& Alkhatib, K. (2017). Proposing a model for limiting earning management practices: The case of Jordanian listed firms. Corporate Board. Corporate Board: role, duties and composition, 12(3), 81-84.

Al-Sraheen, D.A.O, \& Saleh, I.H. 2017). Does the monitoring mechanisms considered as dilemma against the practices of earnings management. International Business Research, 10(10), 39-44.

Alves, S. (2014). The effect of board independence on the earnings quality: Evidence from Portuguese listed companies. Australasian Accounting Business \& Finance Journal, 8(3), 23-44.

Armstrong, C. S., Core, J. E., \& Guay, W. R. (2014). Do independent directors cause improvements in firm transparency? Journal of Financial Economics, 113(3), 383-403.

Berg, A., \& Nenova, T. (2004). Report on the observance of standards and codes (ROSC): Corporate governance country assessment -Jordan. Washington, D.C.: World Bank- IMF.

Cavaco, S., Challe, E., Crifo, P., Rebérioux, A., \& Roudaut, G. (2014). Board independence and operating performance: Analysis on (French) company and individual data. Retrieved from https://hal.archives-ouvertes.fr/hal-00919408v2/document

Chang, S. L., Hwang, L. J., Li, C. A., \& Jhou, C. T. (2018). Managerial overconfidence and earnings management. International Journal of Organizational Innovation (Online), 10(3), 189-205.

Chee, H. K., Phua, L. K., \& Yau, D. L. I. (2016). The relationship between audit quality, board Independence and audit committee independence on earnings management before and after full convergence of IFRS. The Social Sciences, 11(20), 4902-4906.

Chen, C. J., \& Jaggi, B. (2000). Association between independent non-executive directors, family control and financial disclosures in Hong Kong. Journal of Accounting and Public policy, 19(4-5), 285-310.

Chen, X., Cheng, Q., \& Wang, X. (2015). Does increased board independence reduce earnings management? Evidence from recent regulatory reforms. Review of Accounting Studies, 20(2), 899-933.

Chen, Y., Knechel, W. R., Marisetty, V. B., Truong, C., \& Veeraraghavan, M. (2016). Board Independence and internal control weakness: Evidence from SOX 404 Disclosures. Auditing: A Journal of Practice \& Theory, 36(2), 45-62. 
Claessens, S., \& Fan, J. (2002). Corporate governance in Asia: A survey. International Review of Finance, 3(2), 71-103.

Daghsni, O., Zouhayer, M., \& Mbarek, K. B. H. (2016). Earnings Management and Board Characteristics: Evidence from French Listed Firms. Account and Financial Management Journal, 1(2).

Daghsni, O., Zouhayer, M., \& Mbarek, K. B. H. (2016). Earnings Management and Board Characteristics: Evidence from French Listed Firms. Account and Financial Management Journal, 1(2).

Daoud, K., Al-Sraheen, D., \& Alslehat, N. (2015). The moderating effect of an audit committee on the relationship between non-audit services and corporate performance. Research Journal of Finance and Accounting, 6(14), 170-179.

Davidson, R., Goodwin-Stewart, J., \& Kent, P. (2005). Internal governance structures and earnings management. Accounting and Finance, 45(2), 241-267.

Dechow, P., Sloan, R., \& Sweeney, A. (1995), Detecting Earnings Management. The Accounting Review, 70(2), 193-225.

Fan, H. (2017). Earnings management, politically connected CEOs, and politically connected independent board members: Evidence from China. International Journal of Accounting and Financial Reporting, 7(1), 291-310.

Frankel, R., McVay, S., \& Soliman, M. (2011). Non-GAAP earnings and board independence. Review of Accounting Studies, 16(4), 719-744.

Hair, J. F., Black, W. C., Babin, B. J., Anderson, R. E., \& Latham, R. (2010). Multivariate data analysis $\left(7^{\text {th }} \mathrm{ed}\right)$. New York, New York: Pearson.

Ho, S., \& Wong, K. (2001). A study of the relationship between corporate governance structures and the extent of voluntary disclosure. Journal of International Accounting, Auditing and Taxation, 10, 139-156.

Hu, H. W., Tam, O. K., \& Tan, M. G.-S. (2010). Internal governance mechanisms and firm performance in China. Asia Pacific Journal of Management, 27(4), 727-749

Jaafar, A., \& El-Shawa, M. (2009). Ownership concentration, board characteristics and performance: evidence from Jordan. In M. Tsamenyi \& S. Uddin (Eds.), Accounting in Emerging Economies (pp. 73-95). Bingley, England: Emerald Group Publishing Limited.

Jaggi, B., Leung, S., \& Gul, F. (2009). Family control, board independence and earnings management: Evidence based on Hong Kong firms. Journal of Accounting and Public Policy, 28(4), 281-300.

Jiraporn, P., \& DaDalt, P. J. (2009). Does founding family control affect earnings management? Applied Economics Letters, 16(2), 113-119.

Jones, J. (1991). Earnings management during import relief investigations. Journal of Accounting Research, 29(2), 193-228.

Kazemian, S., \& Sanusi, Z. M. (2015). Earnings management and ownership Structure. Procedia Economics and Finance, 31, 618-624. 
D. A.-D. AL-SRAHEEN, K. A. AL DAOUD: Does the presence of independent directors reduce the practice of earnings.. EKONOMSKI PREGLED, 69 (6) 638-654 (2018)

Khalil, M., \& Ozkan, A. (2016). Board Independence, Audit Quality and Earnings Management: Evidence from Egypt. Journal of Emerging Market Finance, 15(1), 84-118.

Labelle, R., Hafsi, T., Francoeur, C., \& Amar, W. B. (2018). Family firms' corporate social performance: a calculated quest for socioemotional wealth. Journal of Business Ethics, 148(3), 511-525.

Leuz, C., Nanda, D., \& Wysocki, P.D. (2003). Earnings management and investor protection: An international comparison. Journal of Financial Economics, 69(3), 505-527.

Liu, M., Shi, Y., Wilson, C., \& Wu, Z. (2017). Does family involvement explain why corporate social responsibility affects earnings management?. Journal of Business Research, 75, 8-16.

Marashdeh, Z. M. S. (2014). The effect of corporate governance on firm performance in Jordan. (Unpublished doctoral dissertation). University of Central Lancashire, Preston, United Kingdom. Retrieved from http://clok.uclan.ac.uk/11163/1/ Marasdeh\%20Zyad\%20Final\%20e-Thesis\%20\% 28Master\% 20Copy\%29.pdf

Marra, A., Mazzola, P., \& Prencipe, A. (2011). Board monitoring and earnings management pre-and post-IFRS. The International Journal of Accounting, 46(2), 205-230

Mengoli, S., Pazzaglia, F., \& Sandri, S. (2017). Family Ownership and Earnings Quality: Evidence from Different Institutional Environments.

Mohamad, N. R., Abdullah, S., Zulkifli Mokhtar, M., \& Kamil, N. F. (2010). The effects of board independence, board diversity and corporate social responsibility on earnings management.

Poretti, C., Schatt, A., \& Bruynseels, L. (2018). Audit committees' independence and the information content of earnings announcements in Western Europe. Journal of Accounting Literature, 40, 29-53.

Rodriguez-Ariza, L., Rodriguez-Ariza, L., Martínez-Ferrero, J., Martínez-Ferrero, J., Bermejo-Sánchez, M., \& Bermejo-Sánchez, M. (2016). Consequences of earnings management for corporate reputation: Evidence from family firms. Accounting Research Journal, 29(4), 457-474.

Saleem Salem Alzoubi, E. (2016). Ownership structure and earnings management: evidence from Jordan. International Journal of Accounting \& Information Management, 24(2), 135-161.

Shin, H., \& Park, S. (2018). Do foreign investors mitigate anchoring bias in stock market? Evidence based on post-earnings announcement drift. Pacific-Basin Finance Journal, 48, 224-240.

Sraheen, D. O., Fadzil, F. H., \& Ismail, S. (2014). Does corporate governance matter? Evidence from accounting conservatism practices among Jordanian listed companies. International Journal of Learning and Development, 4(4), 64-80.

Tabachnick, B. G., Fidell, L. S., \& Osterlind, S. J. (2001). Using multivariate statistics (4 $^{\text {th }}$ ed.). Needham Heights, Massachusetts. Allyn and Bacon.

Tam, O. K., \& Tan, M. G. S. (2007). Ownership, governance and firm performance in Malaysia. Corporate Governance: An International Review, 15(2), 208-222. 


\title{
JE LI PRISUTNOST NEOVISNIH DIREKTORA SMANJUJE PRAKSE UPRAVLJANJA PLAĆAMA? MODERIRAJUĆA ULOGA KONCENTRACIJE OBITELJSKOG VLASNIŠTVA
}

\author{
Sažetak
}

Iako se često kritizira, neovisnost direktora ostaje ključni kriterij za procjenu učinkovitosti nadzorne uloge odbora direktora. Ovo istraživanje ispituje odnos između neovisnosti odbora direktora i upravljanja plaćama, s posebnom pažnjom na moderirajuću ulogu koncentracije obiteljskog vlasništva na ovaj odnos, a uz pomoć uzorka uslužnih korporacija koje su na ammanskoj burzi. Ovo istraživanje je potvrdilo značajnu, negativnu povezanost između neovisnosti odbora direktora i upravljanja plaćama. Osim toga, moderirajuća uloga obiteljskog vlasništva na ovu korelaciju je također bila negativna. Stoga se nadzorna uloga odbora direktora pokazala neučinkovita zbog koncentracije obiteljskog vlasništva. Rezultati su dobiveni korištenjem višestruke i sekvencijske regresijske analize podataka u razdoblju od 2013. do 2016. godine. Istraživanje pruža nove ideje za buduća istraživanja kao što su ispitivanje utjecaja kretanja kapitala i investitora iz susjednih zemalja kao što su Sirija i Irak.

Ključne riječi: neovisnost odbora, obiteljsko vlasništvo, upravljanje plaćama, ammanska burza 